\title{
Beet seed priming with growth regulators
}

\section{Condicionamento fisiológico de sementes de beterraba com reguladores de crescimento}

\author{
Lucas Dotto ${ }^{1}$; Vanessa Neumann Silva ${ }^{2 *}$
}

\begin{abstract}
Seed priming is a technique used to induce metabolic germination processes. Use of growth regulators in seed priming may facilitate increments in physiological processes during seed germination. The objective of this study was to evaluate the effect of priming and growth regulators on beet seed germination. The treatments were cultivar type (Early Wonder, Itapuã and Maravilha) and seed priming technique, which included a control (unconditioned seed) standard hydropriming (water) and a conditioning with salicylic, gibberellic and ascorbic acids, respectively. The treatments were defined by initially testing $0,1,2$ and $4 \mathrm{mM}$ ascorbic, gibberellic and salicylic acids. Before seed priming, imbibition seed curves were established to determine the optimal conditioning time. After conditioning, the germination, rate of germination, seedling length and seedling dry weight were evaluated. First, the appropriate dosage for conditioning was determined by using a completely randomized experimental design, with four replications per cultivar. Then, a 3 x 5 (cultivar $\mathrm{x}$ conditioning technique) factorial design was adopted. Whenever the results were significant by variance analysis, regression analysis was performed. Finally, Tukey's test was used to compare the means at $\mathrm{P}=0.05$. Beet seed priming alters the potential of germination and is influenced by the cultivar and conditioning technique. Pretreatment with 1-2 $\mathrm{mM}$ ascorbic, gibberellic or salicylic acids, respectively, promotes beet seed germination, whereas at 1-3 mM, the growth of roots and shoots of beet seedlings is promoted. The most effective techniques to promote germination and growth of sugar beet seedlings were priming with water, salicylic acid or gibberellic acid.
\end{abstract}

Key words: Beta vulgaris. Hydropriming. Gibberellic acid. Salicylic acid. Ascorbic acid.

\section{Resumo}

O condicionamento fisiológico é uma técnica que permite a ativação dos processos metabólicos e fisiológicos na germinação das sementes por meio da utilização de reguladores de crescimento. Desta forma, objetivou-se avaliar o efeito do condicionamento fisiológico de sementes de beterraba com reguladores de crescimento. Foram utilizadas três cultivares: Early Wonder, Itapuã e Maravilha, submetidas a cinco tipos de condicionamentos: testemunha (semente não condicionada) hidrocondicionamento padrão (água), condicionamento com os ácidos salicílico, giberélico e ascórbico. Para definição dos tratamentos, foram testadas doses de $0 ; 1 ; 2$ e 4 mMol.L $L^{-1}$ dos ácidos. Previamente ao condicionamento, foram realizadas as curvas de embebição das sementes, para determinação do tempo ideal de condicionamento, logo após, as sementes foram avaliadas quanto à porcentagem e velocidade de germinação, comprimento e massa seca de plântulas. O delineamento experimental utilizado foi inteiramente casualizado com quatro repetições, separado para cada cultivar, determinando-se as dosagens adequadas. Na segunda etapa foi adotado esquema fatorial $3 \times 5$ (cultivares $\times$ tipo de condicionamento). Os resultados foram submetidos a análise de variância e quando esta foi significativa

1 Discente de Agronomia, Universidade Federal do Pampa, UNIPAMPA, Campus Itaqui, RS, Brasil. E-mail: lucas-dotto@hotmail. com

2 Prof ${ }^{a}$ Adjunta, Universidade Federal da Fronteira Sul, UFFS, Chapecó, SC, Brasil. E-mail: vanessa.neumann@uffs.edu.br

* Author for correspondence 
procedeu-se a análise de regressão. Na segunda etapa do trabalho realizou-se comparação de médias com teste de Tukey a $5 \%$ de probabilidade de erro. O condicionamento fisiológico de sementes de beterraba altera o potencial de germinação e a resposta está relacionada com a cultivar utilizada e o tipo de condicionamento. As doses entre 1 e $2 \mathrm{mMol} \mathrm{L}^{-1}$ de ácido ascórbico, giberélico ou salicílico promoveram a germinação de sementes de beterraba e doses entre 1 e $3 \mathrm{mMol} \mathrm{L}^{-1}$ dos ácidos favoreceram o crescimento das raízes e parte aérea das plântulas. O condicionamento fisiológico com água, com ácido salicílico ou com ácido giberélico são as melhores técnicas, dentre as testadas, para promover a germinação e o crescimento de plântulas de beterraba.

Palavras-chave: Beta vulgaris. Hidrocondicionamento. Ácido giberélico. Ácido salicílico. Ácido ascórbico.

\section{Introduction}

Seed quality is fundamental for an adequate plant establishment and is associated with the productive success of the crop. The productivity of beet crop is limited by factors, such as low or irregular germination in the field (TIVELLI et al., 2011), which may be linked to the presence of inhibitory substances in the pericarp on the seed glomerulus (LOPES; NASCIMENTO, 2012).

Some techniques can be used to increase the physiological potential of seeds. For instance, seed priming has been shown to increase germination, with high levels of resistance to stress and productivity (PAPARELLA et al., 2015). In this procedure, the seeds are partially hydrated under the recommended temperature and time, allowing the initiation of the germination metabolic processes. Thus, the initial phases (phase I and II) occur, without phase III (primary root protrusion) (BEWLEY et al., 2013).

According to Paparella et al. (2015), seed priming can be performed with bioactive molecules, microorganisms or secondary metabolites, for example, salicylic or gibberellic acids. These compounds control key biochemical processes during maturation (germination) and plant development, while their exogenous application promotes antioxidant responses (RADHAKRISHNAN et al., 2013).

Gibberellins promote germination (YAMAGUCHI, 2008) by inducing $\alpha$-amylase synthesis in the aleurone layer, which secretes hydrolytic enzymes into the starchy endosperm.
The embryo then uses the sugars released by starch degradation, for their growth (YAN et al., 2014). In addition to controlling seed germination, gibberellins are involved in seedling development (YOUNESI; MORADI, 2015).

Salicylic acid is known as a growth regulator in various plant species. According to Rajjou et al. (2006), salicylic acid stimulates enzyme activities involved in Arabidopsis seed germination, such as enolase, malate dehydrogenase, phosphoglycerate kinase and pyruvate decarboxylase. Its effect on germination is dependent on its concentration in the seeds (RAJJOU et al., 2006; SINGH et al., 2010).

Another metabolite that can be used as a growth regulator is ascorbic acid, which plays a vital role during the initial stages of germination (SOARES; MACHADO, 2007). Catusse et al. (2008) characterized the proteome of beet seeds and found that besides accumulating starch, the perisperm is involved in the metabolism of ascorbic acid, affirming a possible communication between the perisperm and the embryo. Thus, it is likely that this compound is involved in the processes associated with the growth of the embryo that occur during germination, considering that ascorbic acid is an important metabolite in the cell cycle (ZHANG, 2013).

Thus, the objective of this research was to evaluate the effect of seed priming on beet seeds treated with the growth regulators, ascorbic, salicylic and gibberellic acids, respectively. 


\section{Material and Methods}

This study used Beta vulgaris L. seeds of cultivars Early Wonder, Maravilha and Itapuã, from the 2014 crop season. In Brazil, Early Wonder and Maravilha can be sowed throughout the year, whereas Itapuã is sowed between January-May and September-December in Southern Brazil, and all year round in other regions. The experiment was conducted in two stages.

\section{First step}

In this step, the seeds were characterized and the growth regulators and priming conditions were established, using a completely randomized design, with four replications per cultivar. Initial seed characterization consisted of water content and germination analyses, according to the Brazilian Rules for Seed Analysis (BRASIL, 2009). Moisture content was determined by oven drying $3 \mathrm{~g}$ of seeds per cultivar, at $105^{\circ} \mathrm{C}$ for 24 hours. Four replicates per cultivar were analyzed and the results were expressed as a percentage on a wet weight basis (BRASIL, 2009). The germination test was performed on four replicates of 50 seeds per treatment, which were uniformly distributed on two sheets of germination paper, in plastic boxes (11 $\mathrm{x} 11 \times 3.5 \mathrm{~cm}$ ) and covered with a second sheet. The paper was moistened with distilled water in an amount equivalent to 2.5 times the paper dry mass. The plastic boxes were covered with lids and placed in a germination chamber at $20{ }^{\circ} \mathrm{C}$, where they remained for 14 days. Evaluations were performed at 4 and 14 days after initiating the test, thus, accounting for the normal seedlings, according to the Brazilian Rules for Seed Analysis (BRASIL, 2009).

Imbibition curves were established to determine the best duration (hours) for seed priming. Briefly, four replicates of $3 \mathrm{~g}$ of seeds per cultivar were weighed and then distributed on three sheets of germitest paper and covered with three more sheets on a metal screen, equipped with plastic boxes (11 x 11 x $3.5 \mathrm{~cm}$ ) containing $40 \mathrm{ml}$ of distilled water (control) or ascorbic or gibberellic or salicylic acids (separately for each treatment). The boxes were transferred to a biochemical oxygen demand chamber regulated at $20^{\circ} \mathrm{C}$, in which they remained until the primary root emerged. During this period, samples were removed and weighed on a precision scale $(0.0001 \mathrm{~g})$, at hourly intervals for up to 12 hours after initiating the test and at 3-hour intervals from 13 hours until the test concluded. The amount of water/solution absorbed by the seeds for each treatment was calculated by weight difference. The hydration curves were constructed and the appropriate period at which to interrupt the procedure was determined to investigate the effect of seed priming (FERREIRA et al., 2013).

In order to define the growth regulator treatments, initial tests were performed at $0,1,2$ and $4 \mathrm{mM}$ ascorbic acid (AHMAD et al., 2013), gibberellic acid (REZAIE et al., 2012) and salicylic acid (AHMAD et al., 2013), respectively.

The analyzed variables included germination, germination speed index, first germination count and seedling length.

The germination test was carried out using a method adapted from the Brazilian Rules for Seed Analysis (BRASIL, 2009), as previously described. The germination velocity index was performed according to Maguire (1963), which involved daily counts of the number of germinated seeds. The first germination count (4 days after initiating the test) and the seedling growth were used for vigor evaluation. Seedling growth was determined by measuring the seedling length (NAKAGAWA, 1999) of 20 seedlings per replicate, for each cultivar from the germination test, using a graded ruler. The results were expressed in centimeters (NAKAGAWA, 1999).

After the initial evaluations, analysis of variance was conducted and when the F test was significant, regression analysis was performed. The ideal dose of each growth regulator for the second stage of the 
research was determined by interpretation of these analyzes. When the results of the regression analysis were significant, graphs were constructed for representation and when there was no significance, tables were developed.

\section{Second stage}

In the second stage, the treatments consisted of control (unprimed seed), hydropriming (seed conditioned only with water) and priming with ascorbic, salicylic and gibberellic acids, respectively, in a $3 \times 5$ (cultivars $x$ types of seed priming) factorial scheme with four replicates. The germination and vigor tests were performed and the dry mass of the seedlings was determined.

After evaluating the length of the seedlings, they were identified and stored in paper bags, then oven-dried at $80{ }^{\circ} \mathrm{C}$ for 24 hours (NAKAGAWA, 1999). The dry mass (weight) of the seedlings was expressed in grams.

The results were assessed by analysis of variance and the means were compared by Tukey's test $(\mathrm{p}<0.05)$.

\section{Results and Discussion}

The initial characterization of the seeds verified that Early Wonder, Itapuã and Maravilha cultivars had $8.4,10.3$ and $8.45 \%$ moisture contents, respectively, and corresponding germinations of 89 , 93 and 91\%. This information is essential for the development of the research because the humidity influences the duration of the germination phases, and therefore, the duration of the physiological conditioning treatment.

In the imbibition curves, treatments with ascorbic, salicylic and gibberellic acids, respectively, shortened the duration of germination phases I and II, compared to the hydroprimed seeds, for all cultivars (Figure 1). The water and growth regulator solutions altered the osmotic potential and concomitantly changed the seed/substrate water levels, altering the absorption rates. Thus, by reducing the duration of phases I and II, it is possible to increase the speed of germination. According to Nonogaki et al. (2010), germination occurs in three phases, beginning with a rapid water absorption by the seed (phase I), until all matrices and cellular contents are completely hydrated. This step is followed by a period of limited water absorption (phase II). The increase in water uptake associated with phase III is initially brief, followed by a large increase in the imbibition of growing cells and radicle and the subsequent remaining seedling development, with an increase in mitotic divisions and cell expansion.

The physiological seed priming with $1.96 \mathrm{mM}$ ascorbic acid increased the germination percentage (Figure 2A) of Maravilha beet seeds. The cultivars Early Wonder and Itapuã could not be differentiated, except at $2 \mathrm{mM}$ ascorbic acid, with Itapuã showing a relatively greater germination (Table 1). Ascorbic acid is involved in the regulation of cell elongation and progression through the cell cycle (GALLIE, 2013), which are important processes during germination. Goel et al. (2003) verified that water and ascorbic acid priming promoted germination of artificially aged cotton seeds, with a concomitant reduction in lipid peroxidation and partial restoration of the activity of antioxidant enzymes (catalase, superoxide dismutase, peroxidase and glutathione reductase). These antioxidant enzymes have also been found in dry pea seeds (WOJTYLA et al., 2006) and are believed to be not only involved in removal of free radicals generated during imbibition but possibly part of an antioxidant system in seeds that contributes to the repair and protection of biomolecules during germination (NONOGAKI et al., 2010). 
Figure 1. Imbibition curves of beet seeds, Maravilha (०), Itapuã $(\bullet)$ and Early Wonder ( $\square$ ) subjected to hydropriming (A), priming with ascorbic acid (B), gibberellic acid (C) and salicylic acid (D).
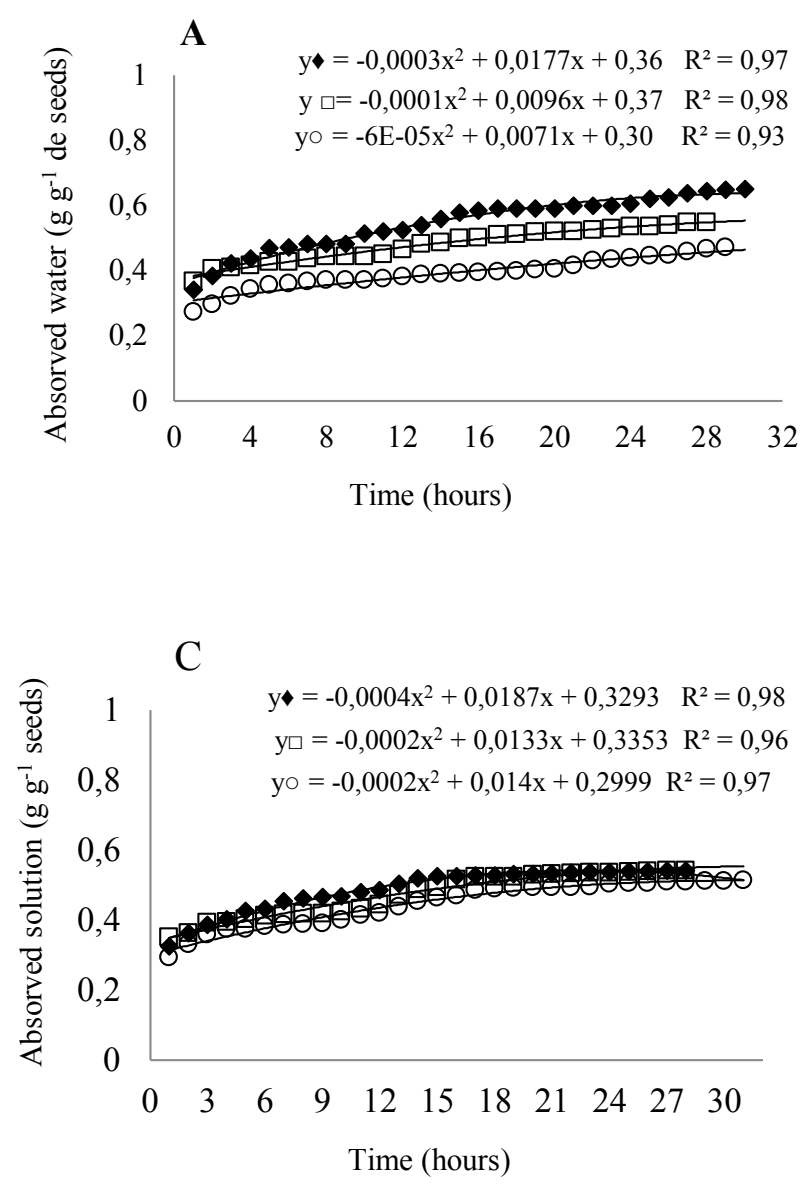

Maravilha and Early Wonder showed a maximum germination speed at 2.08 and $3.13 \mathrm{mM}$ ascorbic acid, respectively (Figure 2B). In contrast, Ansari et al. (2013) studied the effect of hormonal priming on Secale montanum seeds and found the highest vigor index and germination speed occurred at 75 ppm (0.4 $\mathrm{mM})$ ascorbic acid.

Ascorbic acid may have a direct positive influence on the process that redirects available reserve substances for embryo germination because it tends to stimulate the production of enzymes responsible for this process, favoring a better performance (BURGUERESE et al., 2007). Cheng
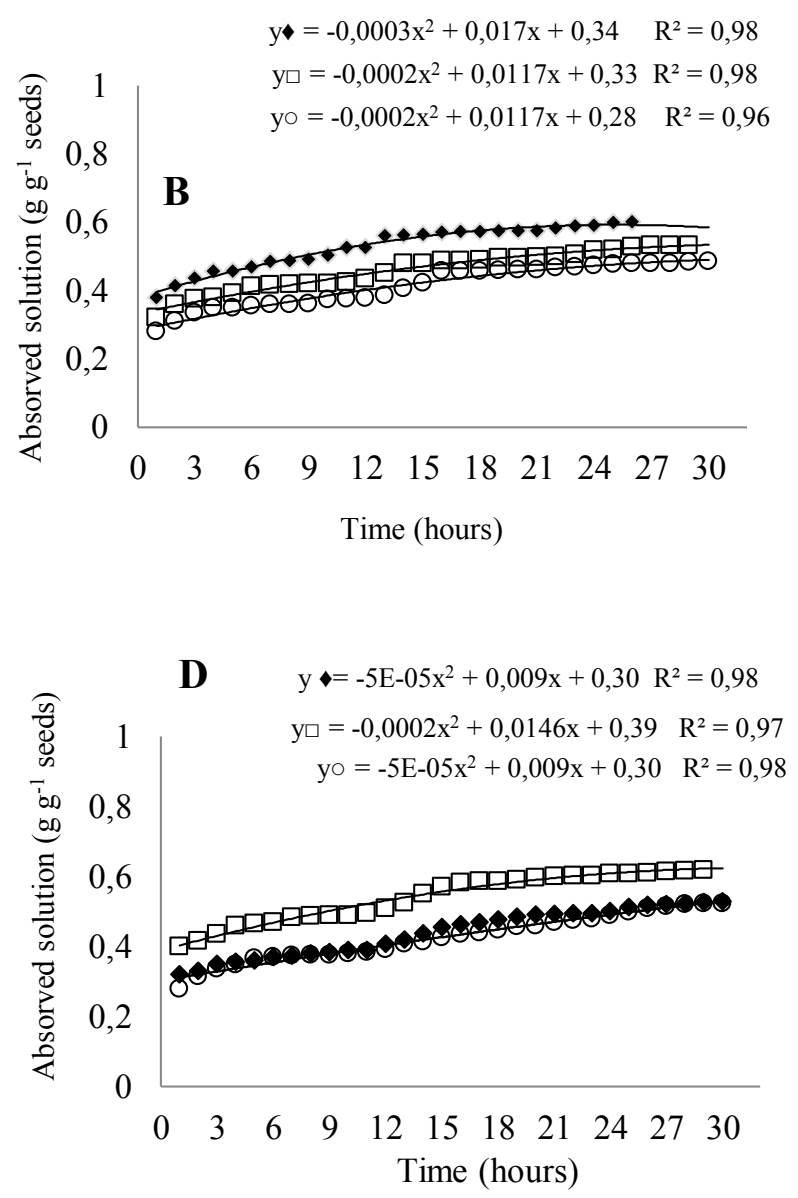

et al. (2014) verified that the enzyme ascorbate peroxidase- 6 regulates the cross-talk between reactive oxygen species and hormones during germination in Arabidopsis. Ascorbate peroxidases comprise a small family of nine enzymes in Arabidopsis that use ascorbic acid as a substrate to reduce hydrogen peroxide to water (MITTLER et al., 2004). Hydrogen peroxide levels in germinating seeds and seedlings can be stimulated via seed priming; This simple method has been shown to be a valuable tool for increasing seed quality and stress tolerance during the post-priming germination period (WOJTYLA et al., 2016). 
Figure 2. Germination (A), germination speed index (B), seedling root length (C) and shoots (D) of beet seeds, cultivars Maravilha $(\diamond)$, Early wonder $(\bullet)$ and Itapua $(\square)$, primed with different doses of Ascorbic acid.
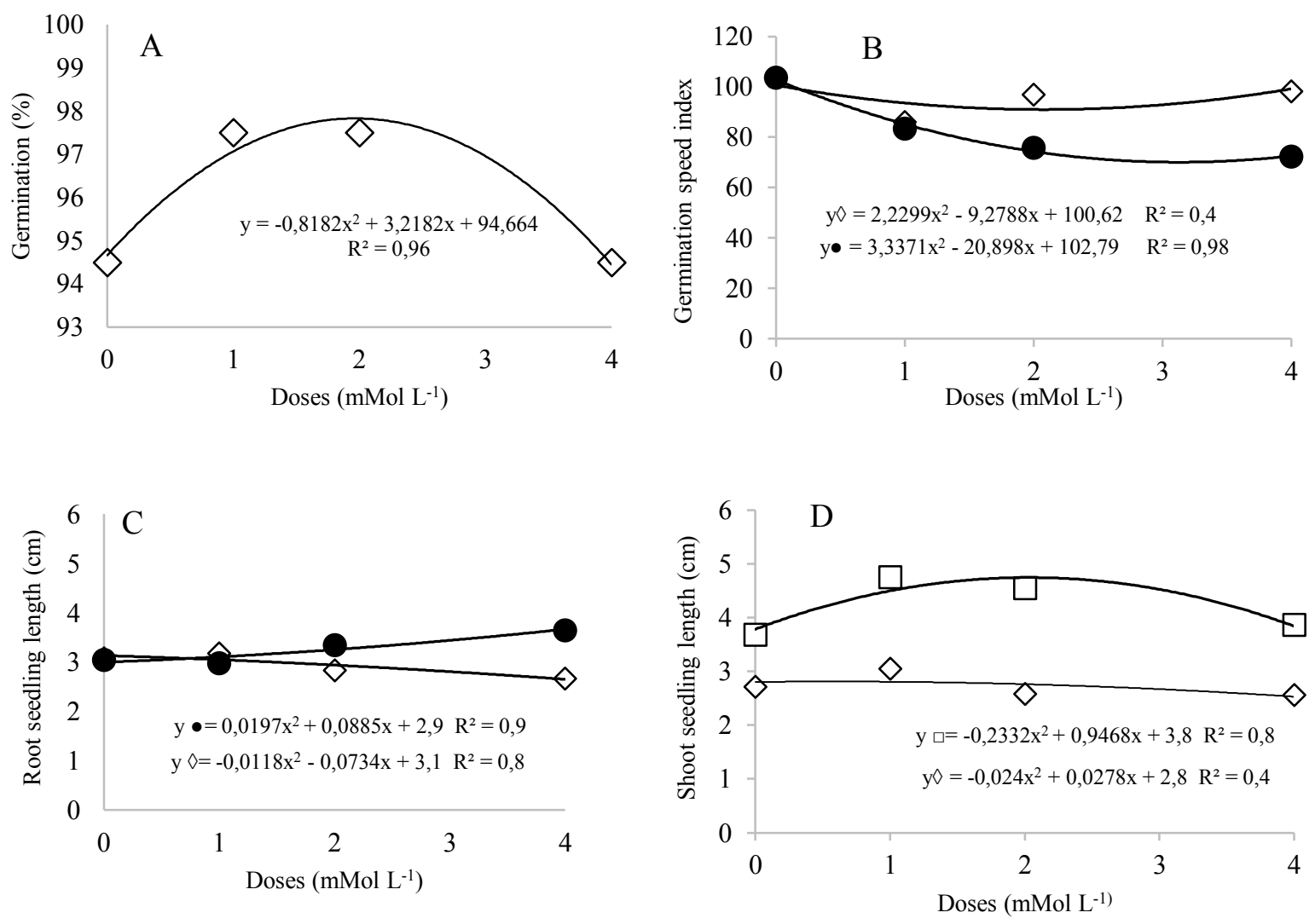

Physiological priming with $1 \mathrm{mM}$ gibberellic acid, increased the seed germination (Figure 2A) of Early Wonder. However, there was no difference between the treatments tested for Itapuã and Maravilha (Table 3). The germination speed of Itapuã was highest at $1.12 \mathrm{mM}$ ascorbic acid (Figure 2B), however, for the other cultivars there was no significance in the regression analysis, and the mean values indicated the low performance of Maravilha at $2 \mathrm{mM}$ ascorbic acid (Table 2).

Gibberellins have a key role in seed germination, overcoming dormancy and controlling the hydrolysis of reserves by inducing $\alpha$-amylase synthesis, the enzyme responsible for starch hydrolysis. Catusse et al. (2012) observed accumulation of $\alpha$-amylase in the perisperm extracted from intact whole seeds, but not from the isolated perisperm, suggesting that the embryo participates in the accumulation of this starch mobilization enzyme during germination.

Thus, the mechanisms that occur in the perisperm of beet seeds appear to be similar to those documented for cereal endosperm.

In seed priming with salicylic acid, germination in Early Wonder was highest at the $4 \mathrm{mM}$ dose (Figure 3A). For Maravilha and Itapuã cultivars, there were no significant results (Table 3). In the first germination count for cultivar Itapuã, there were better results at $1 \mathrm{mM}$ (Figure 3B). According to Rajjou et al. (2006), salicylic acid stimulates the activities of enzymes involved in Arabidopsis seed germination, such as malate dehydrogenase. Cytosolic levels and the activity of malate dehydrogenase are high in seeds of some species during the initial stage of germination (WEITBRECHT et al., 2011). This enzyme participates in the Krebs cycle, also called the citric acid cycle or tricarboxylic cycle and the glyoxylate cycle. 
Table 1. Averages of germination (G), first count of germination (FCG), germination speed index (GSI), seedling root (RL) and shoot (SL) length of beet obtained from seeds primed with different doses of Ascorbic and gibberellic acid.

\begin{tabular}{|c|c|c|c|c|}
\hline \multirow{3}{*}{ Cultivar } & \multicolumn{4}{|c|}{ Doses $\left(\mathrm{mMol} \mathrm{L}^{-1}\right)$} \\
\hline & \multicolumn{4}{|c|}{ Ascorbic acid } \\
\hline & 0 & 1 & 2 & 4 \\
\hline & \multicolumn{4}{|c|}{$\mathrm{G}(\%)$} \\
\hline Early Wonder & $97,5 \mathrm{aA}^{*}$ & $99,0 \mathrm{aA}$ & $94,5 \mathrm{bA}$ & $99,0 \mathrm{aA}$ \\
\hline Itapuã & $97,5 \mathrm{aA}$ & $97,5 \mathrm{aA}$ & $97,5 \mathrm{aA}$ & $99,5 \mathrm{aA}$ \\
\hline \multirow[t]{2}{*}{ CV (\%) } & \multicolumn{4}{|c|}{2,65} \\
\hline & \multicolumn{4}{|c|}{ FCG (\%) } \\
\hline Early Wonder & $76,0 \mathrm{aBC}$ & $95,0 \mathrm{aA}$ & $89,5 \mathrm{aAB}$ & $72,0 \mathrm{bC}$ \\
\hline Itapuã & $85,3 \mathrm{aA}$ & $89,0 \mathrm{abA}$ & $86,0 \mathrm{aA}$ & $96,0 \mathrm{aA}$ \\
\hline Maravilha & $86,7 \mathrm{aAB}$ & $79,3 \mathrm{bB}$ & $96,0 \mathrm{aA}$ & $89,3 \mathrm{aAB}$ \\
\hline \multirow[t]{2}{*}{ CV (\%) } & \multicolumn{4}{|c|}{9,9} \\
\hline & \multicolumn{4}{|c|}{ GSI } \\
\hline Itapuã & $92,5 \mathrm{~A}$ & $85,8 \mathrm{~A}$ & $75,8 \mathrm{~A}$ & $91,3 \mathrm{~A}$ \\
\hline \multirow[t]{2}{*}{ CV (\%) } & \multicolumn{4}{|c|}{10,7} \\
\hline & \multicolumn{4}{|c|}{$\mathrm{SL}(\mathrm{cm})$} \\
\hline Early Wonder & $2,7 \mathrm{~B}$ & $3,7 \mathrm{~A}$ & $2,7 \mathrm{~B}$ & $2,6 \mathrm{~B}$ \\
\hline \multirow[t]{2}{*}{ CV (\%) } & \multicolumn{4}{|c|}{11,2} \\
\hline & \multicolumn{4}{|c|}{$\mathrm{RL}(\mathrm{cm})$} \\
\hline Itapuã & $5,6 \mathrm{~A}$ & $3,2 \mathrm{~B}$ & $3,3 \mathrm{~B}$ & $5,2 \mathrm{~A}$ \\
\hline \multirow[t]{4}{*}{ CV (\%) } & \multicolumn{4}{|c|}{9,8} \\
\hline & \multicolumn{4}{|c|}{ Gibberellic acid } \\
\hline & 0 & 1 & 2 & 4 \\
\hline & \multicolumn{4}{|c|}{$\mathrm{VG}$} \\
\hline Early Wonder & $82,4 \mathrm{bA}$ & $86,6 \mathrm{aA}$ & $93,9 \mathrm{aA}$ & $87,5 \mathrm{aA}$ \\
\hline Maravilha & $94,7 \mathrm{aA}$ & $86,6 \mathrm{aA}$ & $67,8 \mathrm{bB}$ & $94,9 \mathrm{aA}$ \\
\hline \multirow[t]{2}{*}{ CV (\%) } & \multicolumn{4}{|c|}{7,67} \\
\hline & & & $(\%)$ & \\
\hline Itapuã & 99,5 & 99,0 & 96,5 & 99,5 \\
\hline Maravilha & 98,0 & 97,0 & 98,0 & 97,0 \\
\hline CV (\%) & & & 17 & \\
\hline & & & S(\%) & \\
\hline Itapuã & 74,8 & 71,1 & 74,1 & 71,6 \\
\hline Maravilha & 68,7 & 68,2 & 67,8 & 70,8 \\
\hline CV (\%) & 5,46 & & & \\
\hline & & & $(\mathrm{cm})$ & \\
\hline Itapuã & $4,9 \mathrm{~B}$ & $2,6 \mathrm{D}$ & $3,8 \mathrm{C}$ & $5,5 \mathrm{~A}$ \\
\hline CV (\%) & & & 33 & \\
\hline & & & $(\mathrm{cm})$ & \\
\hline Maravilha & $4,0 \mathrm{~B}$ & $3,8 \mathrm{~B}$ & $5,1 \mathrm{~A}$ & $3,9 \mathrm{~B}$ \\
\hline CV (\%) & & & 65 & \\
\hline
\end{tabular}


Table 2. Average of first count of germination (FCG), germination (G), seedling root (CR) and shoot length (SL) of beet obtained from seeds primed with different doses of salicylic acid.

\begin{tabular}{|c|c|c|c|c|}
\hline \multirow{2}{*}{ Cultivar } & \multicolumn{4}{|c|}{ Doses $\left(\mathrm{mMol} \mathrm{L}^{-1}\right)$} \\
\hline & 0 & 1 & 2 & 4 \\
\hline & \multicolumn{4}{|c|}{ FCG (\%) } \\
\hline Early Wonder & $11,1 \mathrm{~B}^{*}$ & $13,5 \mathrm{~A}$ & $11,3 \mathrm{~B}$ & $11,4 \mathrm{~B}$ \\
\hline Maravilha & $80 \mathrm{~A}$ & $66 \mathrm{~B}$ & $80 \mathrm{~A}$ & $75 \mathrm{~A}$ \\
\hline \multirow[t]{2}{*}{ CV (\%) } & \multicolumn{4}{|c|}{1,9} \\
\hline & \multicolumn{4}{|c|}{$\mathrm{G}(\%)$} \\
\hline Itapuã & 98,2 & 99,0 & 89,0 & 96,5 \\
\hline Maravilha & 97,0 & 97,0 & 94,7 & 92,5 \\
\hline \multirow[t]{2}{*}{ CV (\%) } & \multicolumn{4}{|c|}{3,9} \\
\hline & \multicolumn{4}{|c|}{$\mathrm{RL}(\mathrm{cm})$} \\
\hline Early Wonder & 2,9 & 3,4 & 2,8 & 2,0 \\
\hline \multirow[t]{2}{*}{ CV $(\%)$} & \multicolumn{4}{|c|}{3,0} \\
\hline & \multicolumn{4}{|c|}{$\mathrm{SL}(\mathrm{cm})$} \\
\hline Itapuã & 4,3 & 3,6 & 4,5 & 4,3 \\
\hline CV (\%) & \multicolumn{4}{|c|}{3,5} \\
\hline
\end{tabular}

*Means followed by the same capital letter in the row do not differ by Tukey's test $(\mathrm{p}<0.05)$.

Figure 3. Germination (A), germination speed index (B), seedling root (C) and shoot (D) length of beet seeds, cultivars Maravilha $(\diamond)$, Early wonder $(\bullet)$ and Itapua $(\square)$, primed with different doses of gibberellic acid.
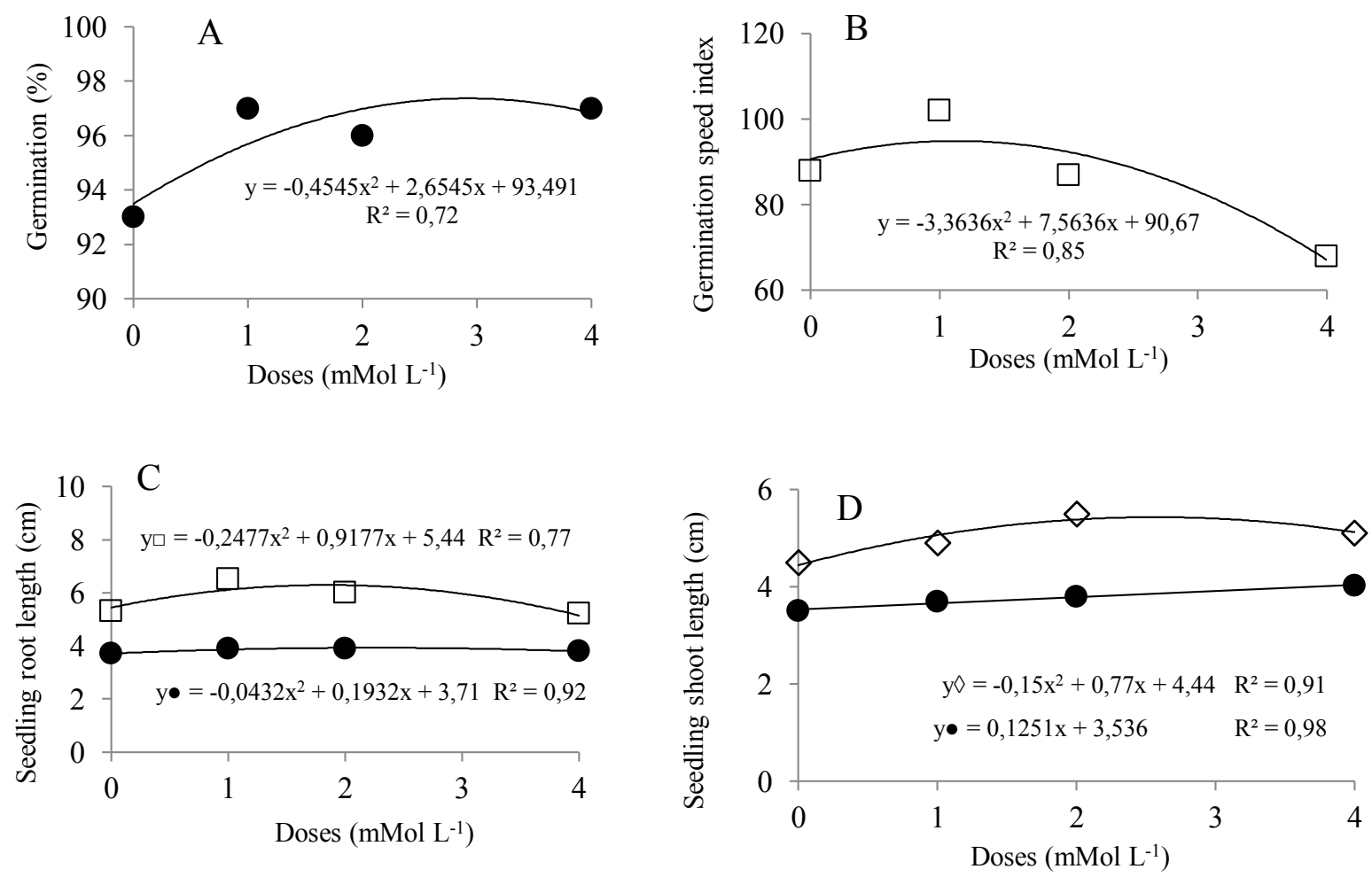
Table 3. Average of first count germination (FCG), germination speed index (SGI), germination (G), seedling shoot (CPA) and root length (CR), seedling shoot (SDM) and root (RDM) dry mass of beet.

\begin{tabular}{|c|c|c|c|c|c|}
\hline \multirow{3}{*}{ Cultivar } & \multicolumn{5}{|c|}{ Treatment } \\
\hline & UP** & $\mathrm{HP}$ & ASP & GA3P & AscP \\
\hline & \multicolumn{5}{|c|}{ FCG $(\%)$} \\
\hline Early Wonder & $97,7 \mathrm{aA}^{*}$ & $61,7 \mathrm{cD}$ & $79,5 \mathrm{cB}$ & $49,0 \mathrm{cE}$ & $69,0 \mathrm{cC}$ \\
\hline Itapuã & $76,7 \mathrm{cC}$ & $69,0 \mathrm{bD}$ & $96,7 \mathrm{aA}$ & $83,7 \mathrm{bB}$ & $77,5 \mathrm{bC}$ \\
\hline Maravilha & $89,2 \mathrm{bB}$ & $95,2 \mathrm{aA}$ & $83,2 \mathrm{bC}$ & $95,0 \mathrm{aA}$ & $83,2 \mathrm{aC}$ \\
\hline \multirow[t]{2}{*}{ CV (\%) } & \multicolumn{5}{|c|}{1,35} \\
\hline & \multicolumn{5}{|c|}{ VG } \\
\hline Early Wonder & $88,5 \mathrm{bB}$ & $66,1 \mathrm{bD}$ & $91,4 \mathrm{aA}$ & $49,7 \mathrm{bE}$ & $70,7 \mathrm{cC}$ \\
\hline Itapuã & $76,6 \mathrm{cB}$ & $65,2 \mathrm{bC}$ & $93,4 \mathrm{aA}$ & $93,6 \mathrm{aA}$ & 75,2 bB \\
\hline Maravilha & $98,6 \mathrm{aA}$ & $98,5 \mathrm{aA}$ & $79,8 \mathrm{bC}$ & $91,5 \mathrm{aB}$ & $93,1 \mathrm{aB}$ \\
\hline \multirow[t]{2}{*}{ CV (\%) } & \multicolumn{5}{|c|}{1,66} \\
\hline & \multicolumn{5}{|c|}{$\mathrm{G}(\%)$} \\
\hline Early Wonder & $100 \mathrm{aA}$ & $92,5 \mathrm{bC}$ & $92,7 \mathrm{bC}$ & $76,5 \mathrm{bD}$ & $96,5 \mathrm{bB}$ \\
\hline Itapuã & $94,2 \mathrm{bB}$ & $87,0 \mathrm{cC}$ & $100 \mathrm{aA}$ & $99,7 \mathrm{aA}$ & $100 \mathrm{aA}$ \\
\hline Maravilha & $98,7 \mathrm{aA}$ & $100 \mathrm{aA}$ & $98,7 \mathrm{aA}$ & $100 \mathrm{aA}$ & $97,0 \mathrm{bB}$ \\
\hline \multirow[t]{2}{*}{ CV (\%) } & \multicolumn{5}{|c|}{0,81} \\
\hline & \multicolumn{5}{|c|}{$\mathrm{SL}(\mathrm{cm})$} \\
\hline Early Wonder & $3,6 \mathrm{aB}^{*}$ & $2,8 \mathrm{Bd}$ & $2,9 \mathrm{cC}$ & $2,9 \mathrm{bCD}$ & $4,6 \mathrm{aA}$ \\
\hline Itapuã & $2,4 \mathrm{cD}$ & $2,7 \mathrm{bBC}$ & $3,7 \mathrm{aA}$ & $2,6 \mathrm{cC}$ & $7,8 \mathrm{cB}$ \\
\hline Maravilha & $3,1 \mathrm{bBC}$ & $4,1 \mathrm{aA}$ & $3,2 \mathrm{bB}$ & $4,2 \mathrm{aA}$ & $3,0 \mathrm{bC}$ \\
\hline \multirow[t]{2}{*}{ CV (\%) } & \multicolumn{5}{|c|}{2,08} \\
\hline & \multicolumn{5}{|c|}{$\mathrm{RL}(\mathrm{cm})$} \\
\hline Early Wonder & $6,0 \mathrm{aA}$ & $3,2 \mathrm{bC}$ & $2,0 \mathrm{cD}$ & $2,1 \mathrm{cD}$ & $5,6 \mathrm{aB}$ \\
\hline Itapuã & $3,2 \mathrm{bB}$ & $1,9 \mathrm{cD}$ & $5,3 \mathrm{aA}$ & $2,8 \mathrm{bC}$ & $3,0 \mathrm{bB}$ \\
\hline Maravilha & $2,4 \mathrm{cD}$ & $6,2 \mathrm{aB}$ & $2,9 \mathrm{bC}$ & $6,9 \mathrm{aA}$ & $2,6 \mathrm{cD}$ \\
\hline \multirow[t]{2}{*}{$\mathrm{CV}(\%)$} & \multicolumn{5}{|c|}{3,01} \\
\hline & \multicolumn{5}{|c|}{ SDM (g) } \\
\hline Early Wonder & $1,1963 \mathrm{bD}^{*}$ & $1,5250 \mathrm{bB}$ & $0,9063 \mathrm{cE}$ & $1,6213 \mathrm{aA}$ & $1,3575 \mathrm{aC}$ \\
\hline Itapuã & $1,4125 \mathrm{aA}$ & $1,3475 \mathrm{cAB}$ & $1,2988 \mathrm{aB}$ & $1,0775 \mathrm{cC}$ & $1,0425 \mathrm{cC}$ \\
\hline Maravilha & $1,3588 \mathrm{aB}$ & $1,6650 \mathrm{aA}$ & $1,1563 \mathrm{bC}$ & $1,3100 \mathrm{bB}$ & $1,1163 \mathrm{bC}$ \\
\hline \multirow[t]{2}{*}{ CV (\%) } & \multicolumn{5}{|c|}{2,8} \\
\hline & \multicolumn{5}{|c|}{ RDM (g) } \\
\hline Early Wonder & $0,5424 \mathrm{aA}$ & $0,4325 \mathrm{bB}$ & $0,3063 \mathrm{cD}$ & $0,3413 \mathrm{cC}$ & $0,5263 \mathrm{aA}$ \\
\hline Itapuã & $0,4713 \mathrm{bB}$ & $0,3863 \mathrm{cC}$ & $0,5663 \mathrm{aA}$ & $0,3763 \mathrm{bCD}$ & $0,3575 \mathrm{bD}$ \\
\hline Maravilha & $0,2175 \mathrm{cD}$ & $0,5263 \mathrm{aA}$ & $0,4638 \mathrm{bB}$ & $0,5513 \mathrm{aA}$ & $0,3550 \mathrm{bC}$ \\
\hline CV (\%) & \multicolumn{5}{|c|}{3,13} \\
\hline
\end{tabular}

In terms of the seedlings growth, seedling root lengths were highest (Figure 2C) at 2.24 and 3.11 $\mathrm{mM}$ ascorbic acid for the cultivars Early Wonder and Maravilha, respectively. However, regression analysis did not present significance for the cultivar Itapuã (Table 1). Seed reserves and their adequate mobilization are responsible for the initial seedling growth, during a relatively short period after emergence (OLIVEIRA et al., 2012). Ascorbic acid is involved in several cellular processes, such as regulating the transition from the $\mathrm{G} 1$ to $\mathrm{S}$ phase in the cell cycle (SMIRNOFF, 1996), a process directly related to root growth. Root treatments with exogenous application of ascorbic acid 
increase the elongation under water stress, which can be attributed to the increased production of nonenzymatic antioxidants that suppress the toxicity of reactive oxygen species and act to regulate the expression of genes associated with degradation of cell wall proteins, thereby controlling cell expansion (XU et al., 2015).

Seed priming with gibberellic acid improved root growth at 1.82, 2.23 and $2 \mathrm{mM}$ for cultivars Itapuã, Early Wonder (Figure 2C) and Maravilha (Table 1), respectively. The seedling length of Maravilha was lowest at a dose of $2.6 \mathrm{mM}$ (Figure 3D) and there was no benefit of the treatments for cultivar Itapuã (Table 1). According to Gupta and Chakrabarty (2013), gibberellic acid may influence cell elongation. Wheat seeds treated with exogenous application of gibberellic acid increase the rate of degradation in the amyloplasts and the nuclei of aleurone cells show structural changes, with degradation occurring more slowly and later than the endosperm starch, these processes accelerated by gibberellic acid (WANG et al., 2016).

Conversely, in salicylic acid priming, the root length (Figure 4C) was greatest at 1.6 and $1.07 \mathrm{mM}$, for Early Wonder and Itapuã cultivars, respectively (Figure 4D). In addition, seedling length was highest at 1.66, 3.0 and $2.25 \mathrm{mM}$ for Early Wonder, Itapuã and Maravilha, respectively. The concentration of salicylic acid significantly influences the percentage and speed of germination, root length and the vigor index of maize seedlings (SALLAM; IBRAHIM, 2015) and also increases the germination, growth and establishment of wheat plants under field conditions (MAGHOSOUDI; ARVIN, 2010).

Figure 4. Germination (A), first count of germination (B), seedling root (C) and shoot length of beet seeds, cultivars Maravilha ( $\mathbf{\Delta})$, Early wonder $(\bullet)$ and Itapua ( $\square$ ), primed with different doses of salicylic acid.
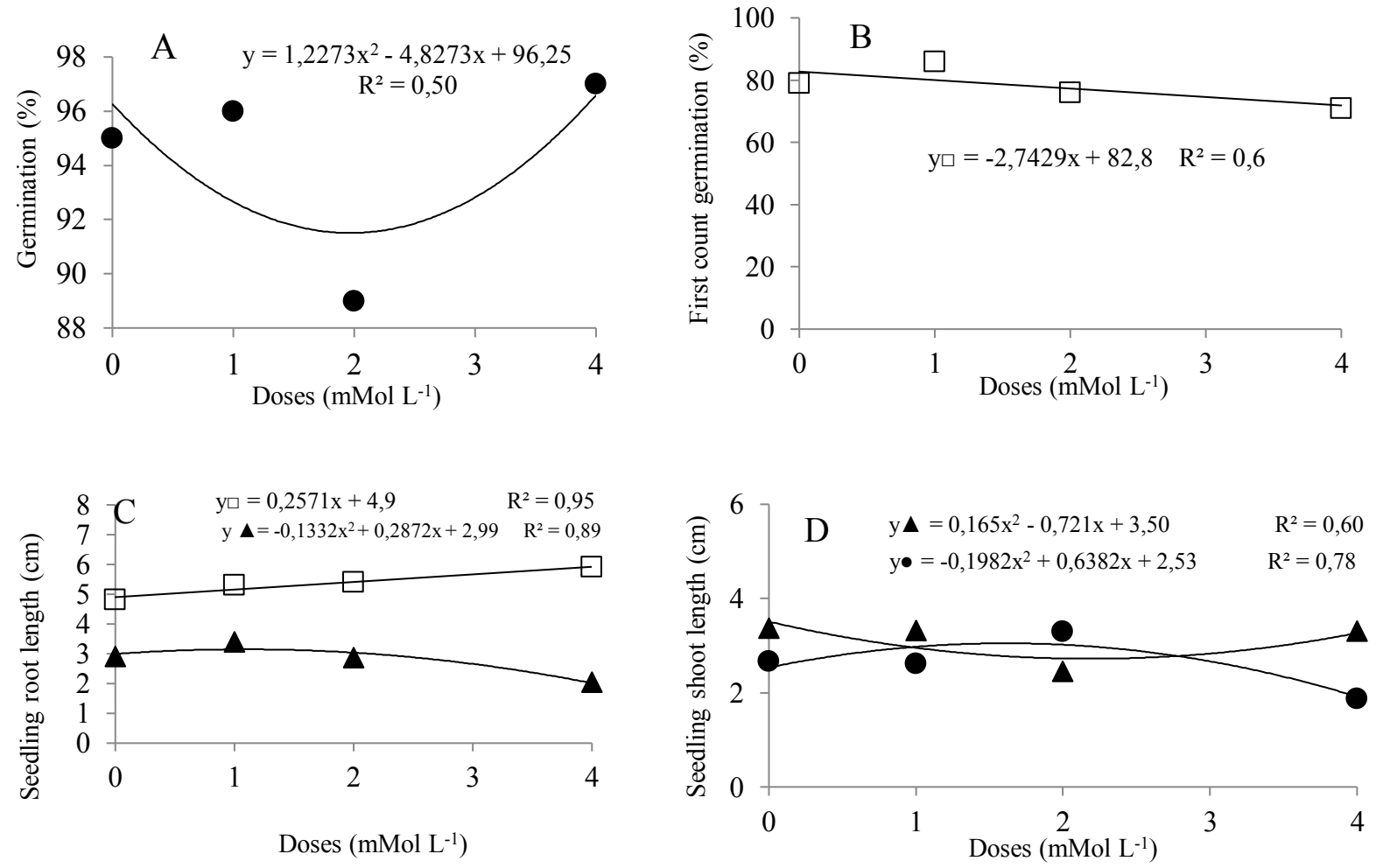
In the second stage of the research, differences between priming procedures were verified. There was a significant interaction between the priming method and cultivar at the first germination count (Table 3). Priming Itapuã with salicylic and gibberellic acids, respectively, and hydropriming Maravilha, propitiated a higher percentage of germination in the first count of the test (Table 3). This rapid germination can be beneficial because it reduces the time for seedlings emergence and consequently of the plants, which, for vegetable producers, is useful for optimizing the process of seedling establishment in the field. In the Early Wonder cultivar, however, there were no benefits of conditioning. However, it already had 97.7\% germination (control-unconditioned).

The seed pre-hydration to advance of germination metabolism followed by the dehydration, before sowing, allowed development of the priming technique, a method that modifies the germination process to increase the performance of seeds in agriculture (BEWLEY et al., 2013). Dias et al. (2009) found that beet seeds exposed to osmotic conditioning in water for $16 \mathrm{~h}$, followed by fungicide treatment $(0.004 \%$ Metalaxyl) had the most positive influence in the germination test and on the establishment of seedlings in soil, among the treatments studied.

The germination speed index was increased in Early Wonder and Itapuã cultivars. The most effective methods were the conditioning with salicylic and gibberellic acids, respectively, for the Itapuã cultivar but only with salicylic acid for Early Wonder (Table 3).

Increasing the germination speed can facilitate the establishment of plants in the field, thereby helping to attain the adequate plant stand and reducing costs to the producer. The less time spent producing the seedlings, the lower the costs associated with irrigation and inputs. For direct sowing in the field, the ability to minimize the germination time is an important factor that favors the competitiveness of the crops over the weeds (ROMAN et al., 1999). In beet culture, the best method of weed control is to offer an advantage to the plants because all the aspects that favorably influence the speed of growth of the crop are of fundamental importance for the minimization of the period of interference (GUERRA et al., 2016; VELINI, 1997).

Regarding the final germination percentage, a greater effect of priming for cultivar Itapuã was observed, obtaining $100 \%$ with salicylic and ascorbic acids, respectively (Table 3), a situation desired by any horticulture producer. According to McCue et al. (2000), exogenous application of plant regulators and nutrients to the seeds can cause an increase or modification in plant growth and development.

The highest seedling lengths were observed with ascorbic acid treatment of Early Wonder and Itapuã cultivars and for hydropriming and gibberellic acid for Maravilha (Table 3). Root growth was favored by salicylic acid priming treatments of Itapuã cultivar and hydroconditioning and gibberellic acid conditioning of Maravilha cultivar (Table 3).

For Solanum lycocarpum seeds, hydropriming probably stimulated synthesis and action of hydrolases, such as endo- $\beta$-mannanase, which is involved in the initiation of the germination metabolism in the species, causing weakening and degradation of the endosperm, determining the ability to overcome dormancy and anticipating radicle protrusion (PINTO et al., 2007).

Regarding the accumulation of dry mass, a positive effect of priming with gibberellic acid was observed for the shoots of cultivar Early Wonder. For the dry mass of the seedling roots, priming with ascorbic acid was effective for the cultivar Itapuã, while hydropriming and gibberellic acid were valuable for Maravilha (Table 3).

Distinct responses to physiological priming between two sunflower (Helianthus annuus L.) cultivars were observed by El-Saidy et al. (2011), evaluating the effect of seed priming using various 
priming agents and their concentrations and comparing hydropriming to unprimed seed. The author stated that responses to priming are linked to genetic potential of the cultivar, which leads to differences in the speed of the pre-germinative metabolic activities, from the beginning of the imbibition until the moment of root protrusion.

Seed priming is an important technique for promoting or facilitating the process of establishment of plants. Considering all the results obtained in this research, it can be considered that physiological priming of beet seeds alters the potential of germination and seed vigor. Furthermore, the cultivar of the beet influences the conditioning response.

At 1-2 $\mathrm{mM}$ ascorbic, gibberellic or salicylic acids, respectively, germination (speed and final percentage) of beet seeds is promoted, whereas at 1-3 $\mathrm{mM}$, the roots and shoot growth of beet seedlings is promoted. In general, physiological priming with water or salicylic or gibberellic acids, respectively, are the best techniques, among those tested, to promote the germination and growth of beet seedlings.

\section{Conclusions}

The physiological priming of beet seeds alters seed germination and vigor potential and the response varies according to the cultivar used and the type of conditioning adopted.

Germination of beet seeds is promoted at $1-2 \mathrm{mM}$ ascorbic, gibberellic or salicylic acids, respectively, while at 1-3 mM, the growth of roots and shoot of beet seedlings are promoted.

Physiological priming with water or salicylic or gibberellic acids, respectively, are efficient to promote seed germination and growth of beet seedlings.

\section{References}

AHMAD, I.; BASRA, S. M. A.; AFZAL, I.; FAROOQ, M.; WAHID, A. Growth improvement in spring maize through exogenous application of ascorbic acid, salicylic acid and hydrogen peroxide. International Journal of Agriculture and Biology, Faisalabad, v. 15, n. 1, p. 95100, 2013.

ANSARI, O.; AZADI, M. S.; SHARIF-ZADEH, F.; YOUNESI, E. Effect of hormone priming on germination characteristics and enzyme activity of mountain Rye (Secale montanum) seeds under drought stress conditions. Journal of Stress Physiology \& Biochemistry, Irkutsk, v. 9, n. 3, p. 61-71, 2013.

BEWLEY, J. D.; BRADFORD, K. J.; HILHORST, H. W. M.; NONOGAKI, H. Seeds: physiology of development, germination and dormancy. Springer: New York. 2013. $392 \mathrm{p}$.

BRASIL. Ministério da Agricultura, Pecuária e Abastecimento. Regras para análise de sementes. Brasília: MAPA/ACS, 2009. 399 p.

BURGUERESE, E.; MCCUE, P.; KWON, Y-I.; SHETTY, K. Effect of Vitamin C and folic acid on seed vigour response and Phenolic-linked antioxidant activity. Bioresource Technology, Essex, v. 98, n.7, p. 1393-1404, 2007.

CATUSSE, J.; JOB, C.; JOB, D. Proteomics reveals a potential role of the perisperm in starch remobilization during sugarbeet seed germination. In: AGRAWAL, G. K.; RAKWAL, R. Seed development: omics technologies toward improvement of seed quality and crop yield. Netherlands: Springer, 2012. cap. 1, p. 27-41.

CATUSSE, J.; STRUB, J-M.; JOB, C.; DORSSELER, A. V.; JOB, D. Proteome-wide characterization of sugarbeet seed vigor and its tissue specific expression. PNAS, Washington, v. 105, n. 29, p. 10262-10267, 2008.

CHENG, C.; LETNIK, I.; HACHAM, Y.; DOBREVE, P.; BEN-DANIEL, B. H.; VANKOVÁ, R.; AMIR, R.; MILLER, G. Ascorbate peroxidase 6 protects Arabidopsis thaliana desiccating and germinating seeds from stress and mediates crosstalk between ROS, ABA and auxin. Plant Physiology, Washington, v. 166, n. 1, p. 370-383, 2014.

DIAS, M. A.; AQUINO, L. A.; DIAS, D. C. F. S.; ALVARENGA, E. M. Qualidade fisiológica de sementes de beterraba sob condicionamento osmótico e tratamentos fungicidas. Revista Brasileira de Sementes, Londrina, v. 31, n. 2, p. 188-194, 2009. 
EL-SAIDY, A. E. A.; FAROUK, S.; EL-GHANY, H. M. Evaluation of different seed priming on seedling growth, yield and quality components in two sunflower (Helianthus annuus L.) cultivars. Trends in Applied Sciences and Research, Dubai, v. 6, n. 9, p. 977-991, 2011.

FERREIRA, R. L.; FORTI, V. A.; SILVA, V. N.; MELO, S. C. Temperatura inicial de germinação no desempenho de plântulas e mudas de tomate. Ciência Rural, Santa Maria, v. 43, n. 7, p. 1189-1195, 2013.

GALLIE, D. R. L-Ascorbic Acid: a multifunctional molecule supporting plant growth and development. Scientifica, Cairo, v. 2013, n. 1, p. 1-24, 2013.

GOEL, A.; GOEL, A. K.; SHEORAN, I. S. Changes in oxidative stress enzymes during artificial ageing in cotton (Gossypium hirsutum L.) seeds. Journal of Plant Physiology, Stuttgart, v. 160, n. 9, p. 1093-1100, 2003.

GUERRA, N.; SILVA, E. S. B.; TAVARES, A. M.; CARLET, A.; OLIVEIRA NETO, A. M. Interferência de plantas daninhas na cultura da beterraba em semeadura direta e transplantada. RevistaAgro@mbiente On-line, Boa Vista, v. 10, n. 3, p. 235-242, 2016.

GUPTA, R.; CHAKRABARTY, S. K. Gibberellic acid in plant- Still a mystery unresolved. Plant Signaling \& Behavior, Philadelphia, v. 8, n. 9, p. 1-5, 2013.

LOPES, A. C. A.; NASCIMENTO, W. M. Dormência em sementes de hortaliças. Brasília, DF: Embrapa, 2012. 28 p. (Documentos / Embrapa Hortaliças; 136).

MAGHOSOUDI, K.; ARVIN, M. J. Salicylic acid and osmotic stress effects on seed germination and seedling growth of wheat cultivars. Plant Ecophysiology, Kerman, v. 2, n. 1 p. 7-11, 2010.

MAGUIRE, J. D. Speed of germination-aid in selection evaluation for seedling emergence and vigour. Crop Science, Madison, v. 2, n. 1, p. 176-177, 1963.

McCUE, P.; ZHENG, Z., PINKHAM, J. L; SHETTY, K. A model for enhanced pea seedling vigour following low $\mathrm{pH}$ and salicylic acid treatments. Process Biochemistry, London, v. 35, n. 6, p. 603-613, 2000.

MITTLER, R.; VANDERAUWERA, S.; GOLLERY, M.; VAN BREUSEGEM, F. Reactive oxygen gene network of plants. Trends Plant Science, Oxford, v. 9, n.10, p. 490-498, 2004.

NAKAGAWA, J. Testes de vigor baseados no desempenho das plântulas. In: KRZYZANOSKI, F. C.; VIEIRA, R. D.; FRANÇA NETO, J. B. (Ed.). Vigor de sementes: conceitos e testes. Londrina: ABRATES, 1999. p. 21-24.
NONOGAKI, H.; BASSEL, J. W.; BEWLEY, J. D. Germination- still a mistery. Plant Science, Limerick, v. 179, n. 6, p. 574-581, 2010.

OLIVEIRA, A. B.; GOMES-FILHO, E.; ENEASFILHO, J.; PRISCO, J. T.; ALENCAR, N. L. M. Seed priming effects on growth, lipid peroxidation and activity of ROS scavenging enzymes in $\mathrm{NaCl}$-stressed sorghum seedlings from aged seeds. Journal of Plant Interactions, Turin, v. 7, n. 2, p. 151-159, 2012.

PAPARELlA, S.; ARAUJO, S. S.; ROSSI, G.; WIJAYASINGHE, M.; CARBONERA, D.; BALESTRANNI, A. Seed priming: state of the art and new perspectives. Plant Cell Reports, Berlin, v. 34, n. 8, p. 1281-1293, 2015.

PINTO, L. V. A; AMARAL DA SILVA, E. A; DAVIDE, A. C.; MENDES DE JESUS, V. A.; TOOROP, P. E.; HILHORST, H. W. M. Mechanism and control of Solanum lycocarpum seed germination. Annals of Botany, London, v. 100, n. 6, p. 1175-1187, 2007.

RADHAKRISHNAN, R.; KHAN, A. L.; LEE, I-J. Endophytic fungal pretreatments of seeds alleviates salinity stress effects in soybean plants. Journal of Microbiology, Daejeon, v. 51, n. 6, p. 850-857, 2013.

RAJJOU, L.; BELGHAZI, M.; HUGUET, R.; ROBIN, C.; MOREAU, A.; JOB, C.; JOB, D. Proteomic investigation of the effect of salicylic acid on Arabidopsis seed germination and establishment of early defense mechanisms. Plant Physiology, Washington, v. 141, n. 3, p. 910-923, 2006.

REZAIE, E. R.; HAGHIGHIKHAH, M.; GHORBANI, S.; KAFI, M. Effect of seed priming on seed germination properties of two medicinal species in the presence of salinity. Journal of Medicinal Plants Research, Nsukka, v. 7, n. 18, p. 1234-1238, 2013.

ROMAN, E. S.; THOMAS, A. G.; MURPHY, S. D. Modeling germination and seedling elongation of common lambsquarters (Chenopodium album). Weed Science, Champaign, v. 47, n. 1, p. 149-155, 1999.

SALLAM, A. M.; IBRAHIM, H. I. M. Effect of grain priming with salicylic acid on germination speed, seedling characters, anti-oxidant enzyme activity and forage yield of teosinte. American-Eurasian Journal of Agricultural \& Environmental Sciences, Dubai, v. 15, n. 5, p. 744-753, 2015.

SINGH, K. P.; CHATURVEDI, K. V.; BOSE, B. Effects of salicylic acid on seedling growth and nitrogen metabolism in cucumber. Journal of Stress Physiology and Biochemistry, Irkutsk, v. 6, n. 3, p. 103-113, 2010. 
SMIRNOFF, N. The function and metabolism of ascorbic acid in plants. Annals of Botany, London, v. 78, n. 6, p. 661-669, 1996.

SOARES, A. M. S.; MACHADO, O. L. T. Defesa de plantas: sinalização química e espécies reativas de oxigênio. Revista Trópica - Ciências Agrárias e Biológicas, Chapadinha, v. 1, n. 1, p. 9-19, 2007.

TIVELLI, S. W.; FACTOR, T. L.; TERAMOTO, J. R. S.; FABRI, E. G.; MORAES, A. R. A.; TRANI, P. E.; MAY, A. Beterraba: do plantio à comercialização. Campinas: Instituto Agronômico \& Fundação IAC, 2011. 45 p. (Série Tecnologia APTA. Boletim Técnico IAC, 210).

VELINI, E. D. Interferências entre plantas daninhas e cultivadas. In: SIMPÓSIO SOBRE HERBICIDAS E PLANTAS DANINHAS, 1., 1997, Dourados. Resumos... Dourados: Embrapa, 1997. p. 29-49.

ZHANG, Y. Ascorbic acid in plants. Springer briefs in plant science. Springer: New York, 2013. 117 p.

WANG, L. L.; CHEN, X. Y.; YANG, Y.; WANG, Z.; XIONG, F. Effects of exogenous gibberellic acid and abscisic acid on germination, amylases, and endosperm structure of germinating wheat seeds. Seed Science and Technology, Zurich, v. 44, n. 1, p. 64-76, 2016.

WEITBRECHT, K.; MULLER, K.; LEUBNERMETZGER, G. First off the mark: early seed germination. Journal of experimental botany, Oxford, v. 62, n. 10, p. 3389-3309, 2011.
WOJTYLA, L.; GARNCZARSKA, M.; ZALEWSKI, T.; BEDNARSKI, W.; RATAJCZAK, L.; JURGA, S. A comparative study of water distribution, free radical production and activation of antioxidative metabolism in germinating pea seeds. Journal of Plant Physiology, Stuttgart, v. 163, n. 12, p. 1207-1220, 2006.

WOJTYLA, L.; LECHOWSKA, K. S.; GARNCZARSKA, M. Different modes of hydrogen peroxide action during seed germination. Frontiers in Plant Science, New Haven, v. 7, n. 66, p. 1-16, 2016.

XU, Y.; XU, Q.; HUANG, B. Ascorbic acid mitigation of water stress-inhibition of root growth in association with oxidative defense in tall fescue (Festuca arundinacea Schreb.). Frontiers in Plant Science, New Haven, v. 6, n. 1, p. 1-14. 2015.

YAMAGUCHI, S. Gibberellin metabolism and its regulation. Annual Review of Plant Biology, Palo Alto, v. 59, n. 1, p. 225-251, 2008.

YAN, D.; DUERMEYER, L.; LEOVEANU, C.; NAMBARA, E. The functions of the endosperm during seed germination. Plant and Cell Physiology, Kyoto, v. 55, n. 9, p. 1521-33, 2014.

YOUNESI, O.; MORADI, A. Effect of different priming methods on germination and seedling establishment of two medicinal plants under salt stress conditions. Cercetări Agronomice în Moldova, Iaşi, v. 48, n. 3, p. 43-51, 2015. 